\title{
EXPLORATORY STUDY ON THE CAPITALIZATION OF ACCOUNTING INFORMATION BY FINANCIAL CONSTRUCTIONS DETERMINED ON THE BASIS OF THE BALANCE SHEET
}

\author{
Alina-Teodora CIUHUREANU \\ alinaciuhureanu@yahoo.com \\ “NICOLAE BĂLCESCU” LAND FORCES ACADEMY, SIBIU, ROMANIA
}

\begin{abstract}
The capitalization of the information provided through the balance sheet should be one of the priorities of the organization's manager. This is because the processed accounting information is the one that contributes to the setting of objectives and strategy and at the same time provides the necessary information capital for proper management of the activity. For these reasons, the article presents a series of financial constructions based on the accounting information provided through the financial accounting system and centralized in the balance sheet. The aim of the paper is to capture the benefits of using it by management and not to detail indicators / rates / tools in terms of calculation methods.
\end{abstract}

\section{KEYWORDS:}

Accounting information, balance sheet, financial accounting, financial position, rates

\section{Introduction}

In the context of capitalizing of accounting information, we believe that we can speak of a series of absolutely fundamental constructions in the entity's general management. Through the exploratory study based on literature, the financial working tools that management has at its disposal by capitalizing the accounting information are further on highlighted. Often, the specific taxation of Romania determines that the financial accounting system is to be regarded mainly by reporting obligations to state institutions, leaving aside the real value of the information provided. However, we believe that all construction and financial balance indicators, financial position indicators should be seen as managerial tools, especially in the context of a changing market economy.

2. Instruments for determining the financial balance

Knowledge of financial balance is important for any user of accounting information (Balteş and Ciuhureanu, 2013). Thus, from the perspective of the 
shareholders, the financial balance is ensured in terms of obtaining the desired profitability after the investment. Managers, as information users, seek to ensure financial flexibility and autonomy as well as economic growth. Creditors are primarily concerned with the liquidity, solvency and ability to pay of the entity in question (Budică and Siminică, 2002). The use of information to establish financial balance is essential to ensure long-term health and long-term financial vitality in parallel with achieving prosperity amid massive changes.

For the capitalization of the accounting information, in the specialized literature, static methods are formed, based on the balance sheet, but also on dynamic methods, based on flows, their presentation being made by specialists in the field (Dragotă et al., 2003; Dumitrescu and Lazăr, 2008; Păvloaia, 2010; Dragotă et al. 2012; Stancu et al., 2015). Based on the opinions of the financial specialists and by supporting our own arguments, we can determine through the construction of the financial balance a series of specific indicators whose useful meanings for the management are presented in the following:

- The working capital reflects the entity's margin of safety in view of the gaps that arise between the time of collection of receivables and the payment of debts. It appears in the form of a permanent, own and borrowed working capital. Regarding the permanent fund, the informational meanings for management reveal for the upper level a possible long-term equilibrium (where the value is positive) generated by a reserve fund to finance the short-term deficit, or the impossibility of providing the long-term financial resources to meet the identified short-term financial needs (where the value of the indicator is negative). In the case of inferior level, management must adopt its policies taking into account the following meanings: the null value is a "critical financial threshold", and measures are needed to swiftly increase the rotation of current assets, and in particular stocks; the positive value confirms the existence of the working capital while the negative value highlights the situation of financial difficulty and represents a signal towards bankruptcy (Mărgulescu et all, 1999; Dragotă et al., 2003). The positive equity value gives management a potential freedom for expansion / development decisions, while negative value requires increased attention. The borrowed fund results from the negative difference between the permanent capital and equity.

- Necessary working capital causes management to achieve a short-term balance. In decision-making, management should consider the value obtained for this indicator, as long as it positively means a resource requirement and negatively denotes the existence of resources.

- The net treasury represents an important indicator for management (Ţugui, 2002), even without realizing this (we are considering micro-entities that are often not interested in such indicators), because it shows the financial surplus (positive value) or deficit, with implications for the financing decision. However, managers need to realize that the goal is not to achieve a high positive treasury because there are emerging opportunity costs involved by not using available funds. Achieving a positive treasury value denotes the optimal financial balance only if that value falls to reasonable levels (Dragotă et al, 2003).

Despite the fact that this type of balance is considered to be less satisfactory for managers by many financial analysts (Bunea, 2001), the usefulness of the financial balance sheet as a tool for determining financial balance can be seen from the perspective of external users (Eros-Stark and Pantea, 2001) .

The construction of the functional balance sheet and of the specific indicators for determining the financial balance, taking into account a number of principles, is more favorable to managers by allowing the financial analysis of the activity on the 
components of investment, exploitation and financing, but at the same time, according to the opinion of specialists Dragotă, Ciobanu and Lipara (2003) has a higher degree of subjectivity for external users. To summarize, the indicators and useful meanings for management generated through the functional balance are the following:

- Net global working capital. A higher value compared to the exploitation needs employed denotes the existence of the necessary liquidities, the reverse situation requiring management to adopt short-term loan decisions. It is recommended that the analysis be correlated with the specificity of the domain in which the entity operates (Niculescu, 1997).

- Total necessary working capital proves useful if both components are analyzed: the working capital requirement for the operation, the positive value of which reflects a normal situation, provided that it is not the result of litigation claims, high stocks or unjustified low level of exploitation debts (Popa et al., 2001), whose positive value translates into the consumer and the positive one shows that it allows the financing of the exploitation.

- Net treasury may be positive, which proves that the entity has the liquidity needed to meet the short or negative debt chargeability, the significance for management being the uncertainty of short-term resources and highlights the liquidity issue.

However, the static analysis finds its limits in the fact that it does not provide a picture of the balance through activities (exploitation, financing, investments) which diminishes the impact on the decisionmaking process. For this reason, the tools for determining the financial balance in a dynamic vision have been created, among which we mention the "needs-resources (sources)" financing picture and the cash flow statement.

The need-resources picture is a complementary, non-binding, synthesis financial document that provides information on how to create the net global working capital and how it is used until the net treasury has been determined. This image, structured in two parts, illustrates how sources have or have allowed the financing of different uses in relation to the entity's current / cyclical / temporary / development / stable needs, and is involved in explaining variations in assets, liabilities, capital and financial structure, ensuring the financial balance between the long-term or shortterm elements, forming the balance of mutations and explaining the variation of the net global working capital and its use (Vintilă, 2002; Mateş et al., 2014).

Ionescu Cicilia (2003) said about the organization that "it can be considered as a cash machine: the cash flow information should show how the machine works". In this context, another construction based on the accounting information provided through general accounting and used in the analysis of the financial balance is the cash flow statement, a mandatory reporting document for medium and large entities defined by OMFP 1802/2014 which, in order to provide useful information to management, it must be built on activities. In order to provide pertinent information to ensure efficiency and future strategies, managers can request the analysis of indicators such as the surplus / deficit generated by the operating treasury, the surplus / deficit generated by the treasury of all management, investment, financing operations.

In conclusion, given that the operations of an entity are at one stage in cash flows, they allow performance to be assessed both in terms of realization and use, being the guarantee of flexibility.

\section{Capitalization of information provided through the balance sheet \\ By using the accounting information for determining the financial position of the company, management mainly operates on the basis of the balance sheet, structure indicators, management rates or other types of indicators being determined.}


Determining assets' structure rates gives the opportunity to express the balance sheet in percent, which allows managers to identify the major features of the entity structure from the perspective of balance components and provides data on the most significant developments over time, so that managers have a more complex view of the composition of the assets held, the managerial utility of the main rates being further shown:

- The fixed asset rates reflect the degree of capital investment within the entity. From the perspective of tangible fixed assets, is reflected the investment policy, the indicator being dependent on the main activity, the strategy, the conditions in which the activity takes place. The meanings are similar for the rate of intangible fixed assets. The underlying significance of the non-current financial assets is reflected in the financial investment policy adopted.

- The current asset rate is useful to management only if it is determined analytically. A first analytical rate is that of receivables through which the trade receivable policy is reflected. Also for commercial policy analysis, the stocks rate is directly related to the scope of the entity. The rate is useful for the management only if it is correlated with the turnover. The ideal situation would be that the inventory index is lower compared to the turnover index and that the renewal of inventory by turnover is as low as possible.

In order to determine how the activity is being carried out, the accounting information can be capitalize by building a multitude of management rates (Dragotă et. al., 2005), based on turnover and different assets, debts or equity that will be used to assess the level of use of the resources at the disposal of the entity.

The most useful meanings of the different management rates can be highlighted as follows:

- The total asset management ratio provides management with information on the effectiveness of asset use and is useful only if its dynamic evolution is pursued. The meanings are relevant if comparisons are made with the average obtained on the branch of activity.

- The fixed asset management rate provides information on the investment policy adopted.

- Current asset management rates are of particular importance especially in terms of stocks and customer receivables. Regarding inventories, it is one of the most relevant indicators that management needs to analyze, being related to the production and / or commercial policy with implications for the entire activity. In order for the capitalization of information to be useful, it must be done in accordance with the rotation rate of customer receivables and supplier credits. Depending on the values obtained, management can adopt acceleration of rotation by reconsidering the supply policy (a rhythmic supply, safety stock, improvement of the storage conditions, etc.), production (product redesigning, process and technological procedure improvement, rational organization of production, internal transport and supply, etc.) and sales (following the sales / collection rate of customers and increasing them). In order to obtain a more detailed picture of inventory management, management is recommended to analyze both the main categories and to determine the safety stocks and the cost of stocks. Regarding the rotation of customer receivables, we believe that meanings are easier to understand if they are expressed in terms of duration in days, reflecting the average timeframe for collecting customer receivables. A value over 30 days should draw the management's attention to the possibility of financial blockings, which in turn generates the most serious consequences for the entity (the impossibility of paying the debt, the use of external sources of financing, expenses etc.)

- Capital management rates. Determined for equity, managerial significance refers to how many times an entity advances and recovers its own resources 
over a financial year. By determining the borrowed capital, the management obtains information on the number of their replenishments (reconstructions) on the basis of the total revenue in a financial year.

- Current debt management rates can be determined mainly for suppliers and other operating liabilities. Regarding the rotation of supplier credits, information is obtained about the average period in which the entity pays its debts to them, i.e. the average time it takes for the supplier loan as a source of current assets financing. It should be noted that both the amount of the debt and the supply will take into account the gross amount. In order to be useful to management, two correlations have to be pursued in the financial balance system: the duration of rotation of supplier credits $>$ the duration of inventory rotation (inventories are determined by the object of activity), which highlights the financing capacity of the exploitation cycle (production / marketing) on the resources procured from suppliers; the duration of rotation of supplier loans $>$ the duration of rotation of receivables-customers, which ensures the ability to obtain a financial surplus.

Although rotation rates depending on the turnover are convenient to calculate, but understandable, values are somewhat affected by superficiality because they involve the perfect link between turnover and balance sheet items. Starting from this informational limit, the well-known specialist Stancu Ion published in 1997 a system of kinetic rates which implies that the turnover ratio is expressed according to the weight of the balance sheet item.

The liquidity issue must be in the constant attention of the managers, they are able to use the balance sheet to determine the liquidity status, through the specific liquidity ratios and the solvency of the entity.

The current liquidity ratio provides management with information on the extent to which liabilities on short term are covered by current assets without resorting to long-term funding sources.
The informational opportunity for management also derives from the fact that, depending on the liquidity level, the investment policy can be developed. If the current activity can not be financed from short-term resources, it can actually be expected to reduce investment (which generally calls for long-term funding) with direct implications for the whole activity. As for the evolution of liquidity, it is not enough that the ratio is over-the-top, but that its meaning is rising. A downward trend illustrates declining activity, with creditors becoming circumspect in providing loans.

The rapid liquidity rate expresses the ability to pay current liabilities from receivables and cash availability. A lower level below the 0.65 minimum accepted by specialists, draws management's attention to the dangers of short-term inability to pay due to inefficient stock management (too much purchases in relation to production and sales). Moreover, exceeding the maximum value of 1.00 indicates for management an incoherent commercial policy from the perspective of debtscustomers management and the risk of noncollection, i.e. a volume of liquidity that is too high, which can have an effect on the entity's development (if not is just a situation that depends on particular circumstances).

The immediate (in-sight) liquidity rate, characterizes the ability of the entity to instantly repay current liabilities on account of already existing liquidities. Although a theoretically high rate indicates good liquidity to the management, in a practical way it may show an inefficient use of current assets. Also, a high value can not contribute to the guarantee of the ability to pay if the other current assets are subject to liquidity risk.

Knowing the overall solvency ratio is of major importance in management because it provides essential information on the ability to cover total debt through its assets, the "relaxation" being achieved by a minimum of 1.66. In the event of the 
adoption of the dissolution decision, it is necessary to recalculate the solvency by taking into account the valuation at liquidation of the assets and liabilities, but taking into account the creditors' hierarchy, the existing guarantees as well as the legal form of the entity.

\section{Final conclusions}

Considering the issues addressed the main contribution of the paper lies in the surprise of the usefulness of the financial constructions which can be established from the balance sheet. Although the balance sheet is often considered a component of financial statements with limited possibilities to capitalize the information, as Feleagă Niculae (1997) said, although ideal information does not exist, an imperfect but perfectible is more valuable, than its lack. The power of indicators consists in the fact that only figures do not reveal the whole reality. Indicators make comparisons and analyzes possible, saying more than figures (Berman and Knight, 2011).

\section{REFERENCES}

Balteş, N., \& Ciuhureanu, A. T. (2013). Consideraţii privind analiza echilibrului financiar al întreprinderii, Conferinţa Ştiinţifică Internaţională "Contabilitatea şi auditul în contextul integrării economice europene: Progrese şi aşteptări”, ASEM Chişinău, 217-220.

Berman, K., \& Knight, J. (2011). Inteligența financiară. Ghidul managerului pentru înțelegerea adevăratei semnificații a cifrelor, București: Editura Curtea Veche, 161.

Budică, I., \& Siminică, M. (2002). Modalităţi de analiză a echilibrului financiar al firmei, Management. Marketing, $n r .4,300$.

Bunea, Şt. (2001). Retratări necesare trecerii de la bilanţul contabil la bilanţul financiar, partea I-a, Contabilitatea, expertiza şi auditul afacerilor, $n r$. 9, 26.

Dragotă, V., et. al,. (2005). Abordări practice în finanțele firmei, București: Editura Irecson, 53-56.

Dragotă, V., Ciobanu, A., \& Lipară, C. (2003). Considerente generale privind analiza funcţională, Finanţe. Bănci, Asigurări, nr. 12, 28.

Dragotă, V., Ciobanu, A., Obreja, L., \& Dragotă, M. (2003). Management financiar, Vol. I: Analiză financiară şi gestiune financiară operaţională, Bucureşti: Editura Economică, 148-149.

Dragotă, V., Ciobanu, A., Obreja, L., \& Dragotă, M. I. (2012). Management financiar, Vol. I: Diagnosticul financiar al companiei, Ediţia a II-a, Bucureşti: Editura Economică, 75-108, 161-179. 171-190.

Dumitrescu, D., \& Lazăr, P. (2008). Finances d'entreprise, București: Editura ASE,

Eros-Stark, L., \& Pantea, M. I. (2001). Analiza situaţiei financiare a firmei, Bucureşti: Editura Economică, 45.

Feleagă, N. (1997). Dincolo de frontierele vagabondajului contabil, București: Editura Economică, 108.

Ionescu, C. (2003). Informarea financiară în contextul internaţionalizării contabilităţii, Bucureşti: Editura Economică, 117.

Mărgulescu, D., Vâlceanu, Gh., Cişmaşu, I., \& Şerban C. (1999). Analiza economicofinanciară, Bucureşti: Editura Fundaţiei „România de Mâine”, 259-262.

Mateș, D., Megan, O., Seucea, M., \& Pușcaş, A. (2014). Tabloul de finanțare, instrument indispensabil în analiza echilibrului financiar al firmei, Contabilitatea, expertiza și auditul afacerilor, $n r .3,26$.

Niculescu, M. (1997). Diagnostic strategic global, Bucureşti: Editura Economică, 385. 
Ministerul Finanțelor Publice. (2014). Ordinul nr. 1802/29.12.2014 pentru aprobarea Reglementărilor contabile privind situațiile financiare anuale individuale și situațiile financiare anuale consolidate, București: Monitorul Oficial nr. 963/30.12.2014.

Păvăloaia, W., et. al. (2010). Analiza economico-financiară. Concepte și studii de caz, Bucureşti: Editura Economică, 282-285.

Popa, A., Dăneţ, A., \& Dăneţ, A. (2001). Management financiar, Bucureşti: Editura Economică, 36.

Stancu, I. (1997). Finanțe. Teoria piețelor financiare, finanțelor întreprinderilor. Analiza și gestiunea financiară, Bucureşti: Editura Economică, 535.

Stancu, I., Obreja Brașoveanu, L., \& Stancu, A. T. (2015). Finanțe corporative. Volumul I - Analiza și planificarea financiară, Bucureşti: Editura Economică, 51-74.

Țugui, I. (2002). Contabilitatea fluxurilor de trezorerie. Modelări, analize și previziuni financiar-contabile, Bucureşti: Editura Economică, 31-35, 52-62.

Vintilă, G. (2002). Gestiunea financiară a întreprinderii, Bucureşti: Editura Didactică şi Pedagogică, 134, 150-155. 